\title{
The Entlebuchers: people from the back of beyond?
}

\section{U. Müller and N. Backhaus}

Division of Human Geography, Department of Geography, University of Zurich, Winterthurerstr. 190, 8057 Zurich, Switzerland

Received: 3 May 2006 - Published in Soc. Geogr. Discuss.: 8 September 2006

Revised: 22 December 2006 - Accepted: 17 January 2007 - Published: 24 January 2007

\begin{abstract}
Incorporated knowledge is structuring the way actors comport themselves and interact with their environment. Knowledge feeds on experiences, especially on recurrent or particularly intense ones. In our media-dominated societies, recurring visual representations of certain facts have a special formative power. Therefore, image analysis provide access to often un-reflected mental images that are to a certain degree the motivations for actions.

With the research project "The power of images" we analysed how images influence sustainable regional development. As case study we analysed the self-determined redefinition of the Swiss Alpine region of Entlebuch as a biosphere reserve. Of the range of approaches open to us, a human geographical perspective was chosen: We were particularly interested in how visual representations suggest certain interactions with space. In order to get an overview of entire, image-laden publications, a quantitative approach was taken using categories of spatial appropriation.

Results show that the outside view conceives the Entlebuch as a largely natural, idyllic region. In terms of the visualization of sustainable development, the biosphere Entlebuch appears to be a nature and landscape conservation project. The inside view (before the crucial poll, where people decided whether to obtain the status of a biosphere reserve or not) looked totally different: In the voter's information brochure the Entlebuch is presented as a (relatively modern) living and production space. Nearly no visual images depicting the Entlebuch as natural environment and idyllic cultural landscape respectively were published. Taking the historical and socio-economical context of the Entlebuch into consideration, the promoters of the biosphere reserve wanted to get rid of its backward image. However, two years after the poll the same promoters changed the way Entlebuch is presented in order to address the values of the target groups
\end{abstract}

Correspondence to: U. Müller

(ursmu@geo.unizh.ch) outside the region. Therefore, mere aesthetic images of nature and cultural landscapes were published.

The study shows that image analysis can provide access to mental images that form part of practical knowledge (or even the unconscious) rather than of verbalised knowledge, for instance those which image producers might not be able to explain well during an interview. We can also detect the use of stereotypes, to which the image producers might not always want to admit. The developed method of image analysis is an attempt to process and analyse a great number of images without neglecting their context nor the reference to the research question.

\section{Introduction}

People's actions are grounded in the meanings they attribute to things. These meanings are constructions that Giddens (1984) suggests can be conceptualized as an element of social structures. The knowledge that these structures represent leaves its mark on all individual actions. This incorporated knowledge then shapes the way people comport themselves and interact with their environment. The knowledge and mental images channel their perception of "reality" and thus reduce its complexity. If a tourist finds out from a guidebook what the recognised sights in a region are, he or she can or will look out for these sights in a way that a tourist lacking the same knowledge would not think of doing (cf. Culler, 1988:166).

The internalisation, storing and the recollection of experiences is of course a complex process (Lester, 2003). Knowledge feeds on experiences, especially on recurrent or particularly intense ones. However, these experiences are not simply stored away mentally but are actively absorbed on the basis of pre-existing mental images. Put another way, they are weighted and combined in line with an individual's interests.

Published by Copernicus GmbH. 
In our media-dominated societies, recurring visual representations of certain facts have a special formative power.

In our research project "The power of images", we analysed how images influence sustainable regional development, using two case studies in Switzerland. The Entlebuch and the Jungfrau-Aletsch-Bietschhorn regions became, of their own initiative, so-called model regions for sustainable development. We learn much about how "image producers" imagine their regions' sustainable development through the way they presented themselves during the application process (viz. a biosphere reserve or a world heritage site). Since the inhabitants of the two regions approved of the sustainable development projects, we can presume that the visualisations during the application process were generally in line with the values and meanings of those consuming them. Whilst the research covered the two areas mentioned, this paper will only deal with the Entlebuch results.

Of the range of approaches open to us, we chose a human geographical perspective. We are particularly interested in how visual representations suggest certain interactions with space, i.e. how the space in each region can or should be appropriated during the process of becoming a biosphere reserve (in the case of the Entlebuch) and a world heritage site (in the case of the Jungfrau-Aletsch-Bietschhorn region). The published images convey notions to the inhabitants about potential spatial relations that they can have within the predefined regions. They show the current land-use activities and those that are possible and desirable.

Behind this approach lies the notion that different social groups can imagine different kinds of spatial appropriation, and that these can result in diverging notions about their region's development and even to conflicts. We can, for instance, assume (at least hypothetically) that environmental activists, in line with their values and interests, will focus on natural features in visual representations of their region. The region will thus be thought of as natural, uncultivated land. The local farmers' association would (again hypothetically speaking) perceive the area differently, more in terms of local farm produce and modern model farms than of protected areas that can no longer be used for agricultural purposes. If these differing ideas of the same region develop further, into visions for its future development (in the case of the project being accepted), conflicts are to be expected. These conflicts can be a consequence of unreflected reproductions of the social images inherent to each group. Therefore, it is an important precondition for sustainable development to take place that these generally internalised and unquestioned social images be dealt with on a discursive level and their impact and consequences explained (cf. Swiss Federal Council, 2002). Since there is no single recipe that can be applied linearly everywhere at any time to reach sustainable development, its content has to be continuously negotiated and re-negotiated. Thus, the achievement of sustainability is strongly associated with the participation of all actors. As a result sustainable development should be communicated in an inclusive way, which makes people feel belonging to the process by taking their concerns serious. Topics that aim at strongly affecting people emotionally (for instance shock images) can lead to polarizations within a population and to the obstruction of the participation process.

We have already explored the opportunities and risks of the use of visual images in communication around sustainable development in previous publications (Müller, 2006a, b). In this paper, we focus on the method we have developed to analyse the content of publications containing large amounts of visual material. Through the use of categories of spatial appropriation, we intend to produce condensed overviews of individual publications so as to be able to compare them with others. Below, we will start by presenting our conception of spatial appropriation before proceeding to define categories of image analysis and their applications. We conclude by demonstrating the potential value of this method and critically discussing it by means of case studies.

\section{Meaningful spaces}

People attribute meanings to "things", and thereby render their environment understandable or valuable to themselves and others. Only through this attribution of meaning do "things" really become things or objects. A large slab of rock can be attributed with the meaning "table" if a hiker spreads out his or her picnic on it, or remain a "rock", an attribution in itself. Something that has not been attributed with meaning remains diffuse, hidden, indeed doesn't exist. "All meaningful reality exists for us because we make it meaningful or because it has been instilled with meaning by our ancestors or neighbours and is still important to us" (Jäger, 2001:17). During their socialisation, people learn about the pre-structured meanings of the material world. They orient themselves in relation to the meanings given by others and thus reproduce them (cf. Giddens, 1984). These internalised and collectively-held meanings - the internalised social world - are what help us make sense of our sensations.

This rough outline of the concept of giving meaning to objects and thus making them appropriable can also be applied to spatial appropriation. The constructivist assumption that meaning is not inherent to objects makes it impossible to understand the term "spatial appropriation" as if the individual were simply incorporating a particular external image as a photograph would. Space only "emerges" through the duality of spatial appropriation, which is a combination of attribution (production) and the incorporation of pre-structured meanings (reproduction). In everyday life, the reproduction of social ideas or images of space (Ipsen, 1997) is done routinely and so often that the meaning of objects (and space) seems to stick to them and to be part of them. Thus space is very often conceived of as a container of objects (cf. Wardenga, 2002). 


\subsection{Physical and mental appropriation of space}

For clarity's sake, we propose to distinguish between physical and mental forms of spatial appropriation. Physical appropriation is the occupation and control of physical space.

\subsubsection{Physical appropriation}

Space that has been physically appropriated is characterised by the fact that people have the possibility to "move freely, to relax, to own it, $[\ldots]$ and to do and create things that reflect their own wishes, demands, expectations and ideas" (Chombart de Lauwe in Weichhart, 1990:38f.; cf. also Scheller, 1995:92). This can mean that people passively insert themselves into an existing spatial structure and feel comfortable doing so (i.e. people trekking on footpaths or campers pitching their tent on the campsite slot they have been allotted). However, spatial appropriation can also lead to a rearrangement of material objects (i.e. building walls, roads or tunnels). Such a rearrangement can both afford new opportunities (for agency) and restrict others. Walls and tunnels by general perception - allow for specific appropriations of space, because they are physical barriers or pathways (Gibson, 1986). Objects can generally only be appropriated symbolically; for example traffic lights prevent cars from advancing, not physically but by the symbolic meaning of the red light (cf. Löw, 2001:153f.).

Whereas physical appropriation of space is (normatively) characterised by the freedom it gives for action, terms such as "spatial alienation" and "spatial disappropriation" indicate the obverse of limited appropriation. Disappropriation means that a defined group cannot make use of a specific space in a particular manner. Motorways are, for example, out of bounds to cyclists and pedestrians. Another example are (strict) conservation areas where local people are forbidden from using the natural resources and literally excluded from nature. This total protection model was predominant until the 1980s (cf. Kollmair et al., 2003). The model required all existing forms of access and use to be discontinued or removed from the protection date onwards. The perception that naturally valuable areas have to be protected is a form of spatial appropriation based on the interests of specific stakeholders (Röper, 2001:49). These interests are rarely in line with those of local people living and working there. Consequently, the implementation of nature conservation schemes depends on the relative power of stakeholder groups to push through their ideas about appropriation against competing ones and to make these ideas commonly binding and enforceable. This in turn depends on these stakeholders' position as well as on the "Zeitgeist", the prevalent atmosphere (cf. Bachmann, 1999, Müller and Kollmair, 2004).

Spatial disappropriation is not necessarily the consequence of the erection of walls, the presence of guards, or an explicit ban. Physical spatial appropriation can be restricted by "mere" mental barriers; for example if somebody believes a certain area should not be entered or if he or she feels out of place there (Bourdieu, 1991). Spatial alienation is a weaker form of disappropriation and does not constrain the possibilities to act quite as severely. The term alienation, in a Marxist sense, expresses the fact that some people are unable to appropriate space in a manner that satisfies their needs and demands. Should they persist regardless, they risk being labelled socially conspicuous or delinquents because of their inappropriate appropriation. As far as possible they will (partially) withdraw from "normal" structures and try to establish subcultural spaces in which they enjoy greater freedom (Reutlinger, 2003).

\subsubsection{Mental appropriation}

The debate about desired forms of spatial appropriation leads us on to a discussion of mental forms of spatial appropriation and their relation to its physical forms. Physical appropriation of space (in its more or less intentional forms) implies that people have a conception of their interactions with (real or fictitious) spatial units. As we conceive of it, people appropriate spaces mentally before they do it physically. Mental appropriations are people's ideas about what certain spatial units mean, what one can expect from them and what one's relation to them can and should be (Topitsch in Thabe, 2002:96). Mental spatial appropriation does not require one to be present in the specific spatial area. The majority of spatial images are transmitted by the media and do not necessarily have to correspond to "reality" (e.g. the image of Cuba as a "paradise that whole generations longed for with their entire soul" (Hard, 1994:55, own translation)). Mental spatial appropriation does not even require the "real" space to exist. Morus' "Utopia" (2003/Orig. 1516) does not refer to a real place; it is indeed a non-existent place. By contrast, physical appropriation - with the exception of unconscious or unintended appropriation - has a mental appropriation as a prerequisite and is, to some extent, a result of it. Going hiking in a certain area is the result of a process of having mentally appropriated it as a hiking area worth visiting. Since humans are physical beings their mental appropriations tend to have consequences for others (Bourdieu, 1991). This is the case if a person decides not to go hiking in an area such as the Entlebuch, because he or she is convinced that it is "always raining there". If he or she then tries to persuade others to emulate his or her decision, the consequences of this mental appropriation are even more apparent. Also a fictitious mental appropriation like "Utopia" has consequences for others as soon as such a concept is communicated to others and thereby influences their view of the world.

Spatial appropriations might appear to be an individual affair. However, they are based on social structures and power relations that regulate the possibilities of appropriation - e.g. by laws governing the purchase of land or conventions about what is beautiful or aesthetic. Such conventionalised attributions of meaning can be called the "social appropriation of 


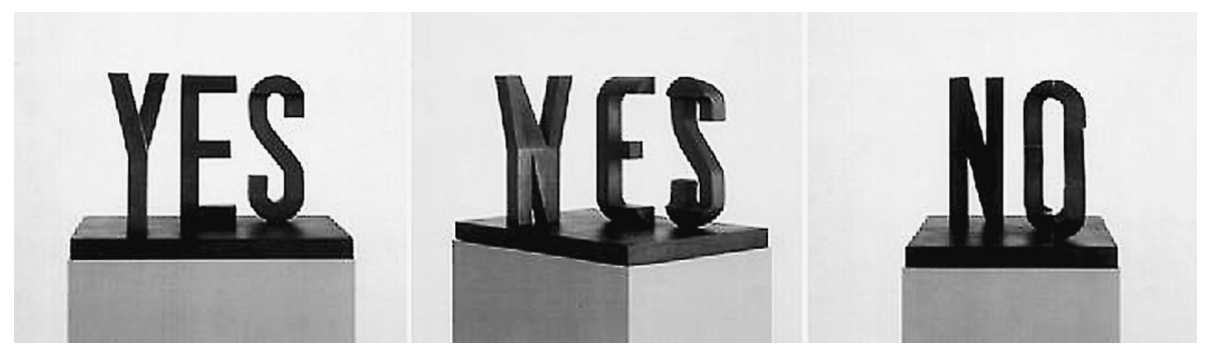

Fig. 1. The position of the beholder determines which side of an object come into view (Markus Raetz, Crossing, 2002; source: http://www.artnet.de/artwork/424037235/_Markus_Raetz_Crossing.html, 15.3.05).

space". Different social groups appropriate space differently according to their members' disposition, which can cause conflicts at the latest when the appropriation becomes physical (Bourdieu, 1991).

\subsection{Regionalization}

Regions are meaningful constructs that are (re-)produced by structured and structuring actions, a process we can call "regionalization" (Hard, 1994:54). In the same way as spatial appropriation, regionalization creates - "bonds with the world", through which people relate to the world, and which they shape physically and symbolically with their geography-making (Werlen, 1997). Regionalization illustrates the social circumstances or structures that are necessary for spatial arrangements to emerge and develop. They have the structuring power to produce meanings, as well as to modify and reproduce them. Regions are thus momentary expressions of regionalization and must be understood as contexts and situations that are connected to meanings (ranging from the vaguest of ideas right up to official laws). Consequently, regionalization often serves to regulate spatial relations that affect the actions of others (Werlen, 1999:264). In a similar way to spatial appropriation, the impacts of regionalization may be physical (e.g. walls, doors), symbolic (e.g. a guidepost) or mental (e.g. "spaces of fear"). On a mental level, regionalization signifies "the creation of concepts and images of regions and their introduction into social exchanges" (Hard, 1994:5) in order to influence the social images of specific spaces. Tourism marketing campaigns and adverts stating the political and economic advantages of a location for business are examples of such regionalization.

\subsubsection{Regionalization as a decomplexification strategy}

Similarly to attributions of meaning in general, the development of a region depends on certain features of that region (or their interpretation) being construed as belonging together and therefore representing an entity that can be delimited from others. Regionalization integrates similar things and excludes what does not fit in the chosen frame. Every reallife situation offers endless possibilities for regionalizations, constructed by combining the most diverse characteristics such as language, modes of living, kinds of agriculture, soil types, climate, amongst others. The way a specific kind of regionalization is achieved depends on the interests of those involved (Hard, 1994:54). "Objective" criteria that support a "natural" classification of "natural" regions, delimited by "natural" borders, are rare and occur only in sub-sectors, in which the grouping appears to coincide with "reality" (Bourdieu, 1990:96). The "reality" of a region as a whole is, in the end, socially constructed through and through (ibid). However, such abstractions fulfil the important function of making a complex reality manageable. Seen this way, regionalization is a decomplexification strategy (Hard, 1994:54) that breaks complex structures down into manageable entities.

Disputes involving regional entities are power struggles about inclusion or exclusion. The struggles are "about the power to enforce principles of social structures (di-visions) and ideas (visions) about the social world. If these principles encounter general social approval, they provide meaning and a consensus about the identity and unity of a group" (Bourdieu, 1990:95). Regionalistic discourses seek to redefine borders and thus help regions gain acceptance as expressions of a particular spatial identity. Scientific discourses also participate in these disputes about classification; "even the most neutral scientific judgement contributes to the alteration of the object of research. Every statement about a region serves as an argument that can be used either in favour or against the recognition - and thereby the existence - of this region" (Bourdieu, 1990:101).

\subsubsection{Spatial appropriations conveyed by the media}

The ideas that people have about the world are shaped by the various media such as TV broadcasts, films, newspapers, magazines, advertisements. As humans are not in a position to witness the endless variety of the world with "their own eyes", Luhmann's statement that "whatever we know about our society, indeed about the world in which we live, we have learnt from the mass media" (Luhmann, 1996:9) rings true. The perspective on the world that we get from the media widens our horizon considerably. The perspective that is given is strongly determined by the standpoint of the image 


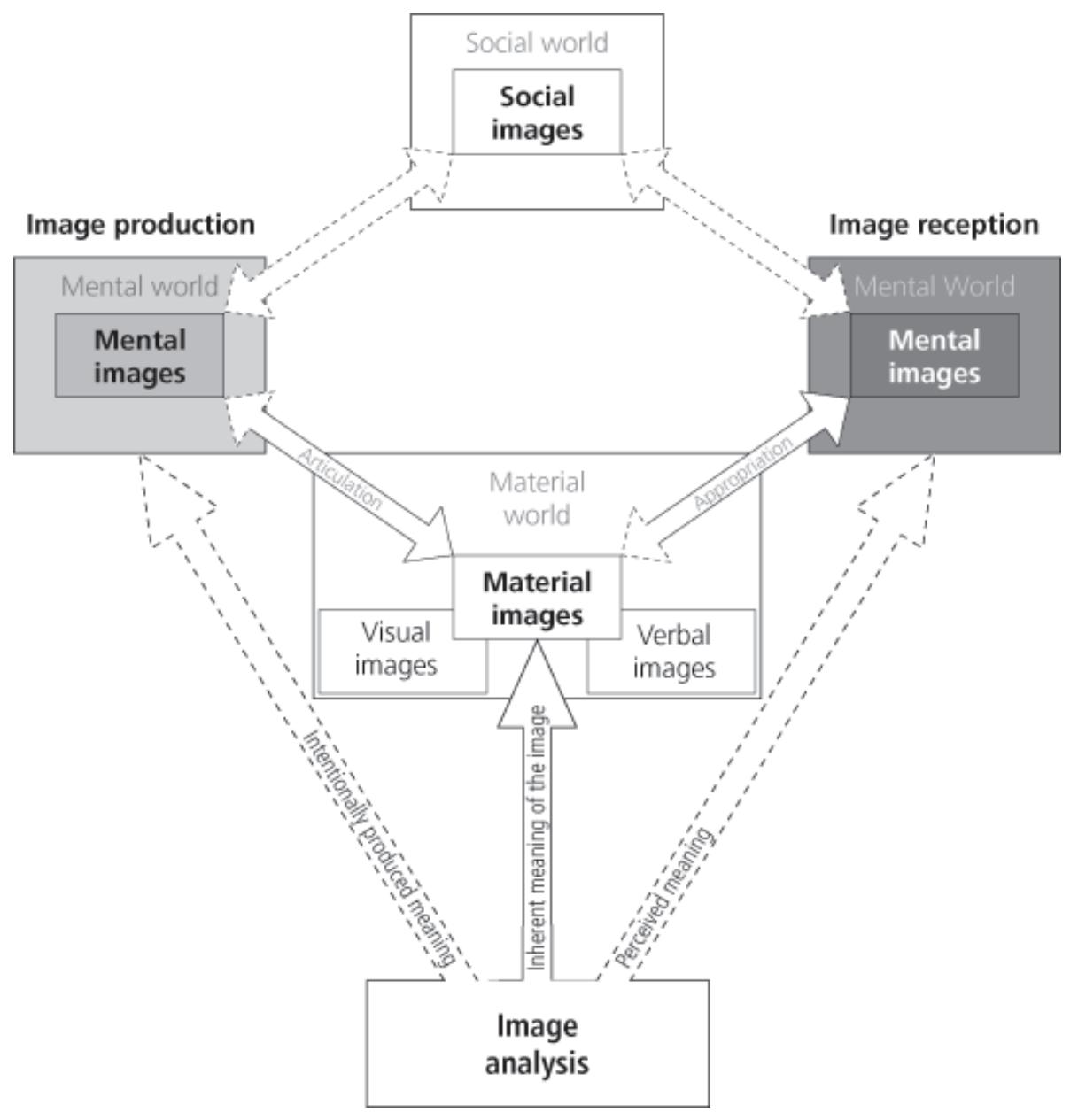

Fig. 2. Model of the theoretical background and the analytical approach to images (graph by U.M.).

producers and their distance from the objects shown (cf. Fischer and Hasse, 2001). This distance can be roughly divided into close and far-off. An object viewed from a close-up can look quite different from the same object seen from farther away. If we understand close and far-off metaphorically in terms of different degrees of affectedness, we can conceptualize how emotional involvement is influencing the mental image of certain issues. The standpoint of the viewer determines which aspects of an object come into view. Amongst a myriad of other factors, an object can reveal completely different aspects if observed either from the front or the back, from above or below (see Fig. 1). Again metaphorically speaking, the standpoint can be seen as a person's social position. The position "determines" the socio-cultural component of a beholders patterns of perception and interpretation. This standpoint can, moreover, vary according to the specific situation a person finds him- or herself in. Something approaching a representative overview can only be reached through a deliberative and democratic process which recognises different points of view as being equally valuable.

\section{Image analysis}

The meanings of visual images that serve the "communication of meaning" (Müller-Doohm, 1997:89) are generated in a three-sided process (cf. Fig. 2). The meanings that image producers (in the broadest sense including e.g. photographers, editors, designers, advertisers) wish to convey materialise, more or less accurately, in the inherent meaning of images. Differences between the producer's intention and the meanings that are materialised within an image are likely to occur. Either due to unreflected ways of looking, lack of production skills or resources and other factors more, the visual image gains an inherent or intrinsic meaning transcending the producers intentions. These inherent meanings of an image open a range of potential ways it can affect image consumers. The context of viewing narrows the range of potential interpretations down, but not necessarily to the meaning the producers had in mind. Further more, the meanings of the producers as well as the effects of images to their audiences might be beyond their capability (or their intention) to discursively express them. Therefore, the analysis of the in- 
herent meaning reveals more than interviews could do, but runs the risk of mis- or over-interpreting an image. The third side of the generation of meaning in visual communication comes into play when images are perceived by image consumers in a specific way leading to an attribution of meaning. Each of the three sides - image producers, image consumers and the material image itself - needs to be handled with the appropriate methods. A comprehensive understanding of visual communication can be obtained through a synthesis of the different research techniques by triangulation of methods (cf. Flick, 2000; Backhaus, 2001).

In this paper, we focus on the analysis of the inherent meaning of visual images. Image analysis allow us to access mental images that form part of practical knowledge (or even the unconscious) rather than of verbalised knowledge, for instance those which image producers might not be able to explain well during an interview. We can also detect the use of stereotypes, to which the image producers might not always want to admit. The method employed must be adapted to the type and frequency of the images to be analysed. Our data consists of a relatively large number of newspaper articles and of some brochures and magazines with a large quantity of visual images (see below). We have therefore adopted a quantitative approach (see next sections) in order to get an overview of whole publications. By applying categories of spatial appropriation to the data, we want to ascertain the kinds of spatial appropriation depicted in the images and thus determine the attribution of space-related meanings and values.

\subsection{Categories of spatial appropriation}

To develop categories of spatial appropriation, we have followed an abductive procedure combining theoretical considerations (deductive) with empirical use of these categories on the available image material (inductive) (for abduction cf. Scheff, 1990). For the deductive part, we start with theoretically known forms of spatial appropriation. We took important indications from the concept of basic functions of existence (Daseingsgrundfunktionen) of the Munich school of social geography (without going into the weaknesses of this specific theoretical approach here) (Werlen, 1988:230f.). These functions are: to live in a community, to have shelter, to work, to feed, to have access to education, and to rest. Mobility and communication are preconditions for these functions to take place. Since these activities take place within "space", i.e. can be materialised, we integrated them into our set of categories. Further thoughts on spatial appropriation were taken from Borghardt et al. (2002), Bozonnet (1992), Brechbühl and Rey (1998), Buwal (2002, 2003), Gamper et al. (1997), Ipsen (1997), Reutlinger (2003), Rodewald (1999) and Stegmann (1997).

As our aim was to assess how people visualise sustainable development, we gave particular importance to the procedural dimension of this concept by including the categories "participation" and "cooperation". The important aspect of problem awareness was recognised by creating a category of "space of problems", and we also included a "research space" category to do justice to the fact that the biosphere reserve Entlebuch project is designed as a research area. A list of categories can be properly applied, if (ideally) all images can be included and categorised (cf. Rose 2001:62). The inductive part starts with the description of images, i.e. detailed paraphrasing of image elements with increasing abstraction from one level to the next (in Fig. 3, from the left to the right side).

It is important, in the abductive process, to allow categories to change hierarchical level. Thus, a sub-category can change into a main category and vice versa. Additional image material can cause categories to emerge from "Miscellaneous" and become categories in their own right. However, during the final classification of the images, the categories may not be modified any further.

The result of an abductive process is a set of abstract categories of appropriation of space that, in principle, can be used for the analysis or interpretation of images of any region. Nevertheless, "Miscellaneous" remains a useful category to capture unexpected and marginal forms of spatial appropriation. The images (or ideal types) used to define and represent each category can, however, vary from region to region depending on their context (i.e. alpine, sub-alpine or lowland). Moreover, a socio-economic "space of problems" might look different in a developing country compared to our case study area, the Entlebuch. While the detailed description of the categories will differ in different spatial contexts, we can assume that the abstracted categories themselves remain sufficiently useful. However, further comparative research would be necessary to prove this.

During categorisation, we differentiate between primary and secondary occurrence. While primary forms dominate the image or its focal point, secondary forms can be found in the background or at the edge of an image. This differentiation allows more detailed analysis that is able to situate a primary form of spatial appropriation within its context (i.e. the scenery).

The reliability of the category definitions and of their coding (i.e. how they are applied to the data) is approached through independent coding of the same data sample by different coders and subsequent comparison of the results (intercoder reliability). In addition, the same coders have coded different sets of data and, in some cases, the same data after a certain time, and the fact that the results remained constant testifies to good intra-coder reliability (cf. Bell, 2001:22), Nevertheless, the degree of reliability depends on precise and unmistakable descriptions of the categories, as well as intensive induction and training of the coders. 


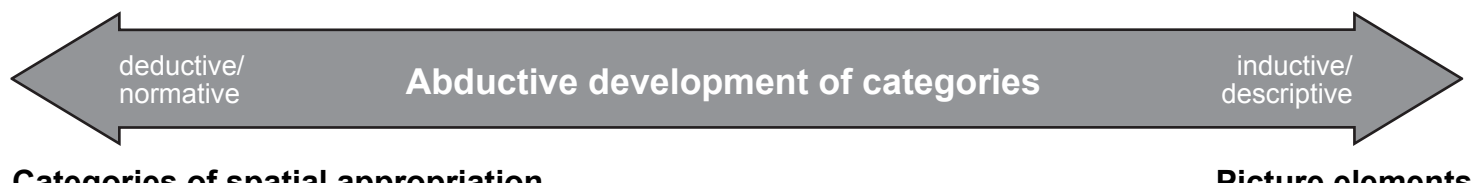

\section{Categories of spatial appropriation}

Natural environment

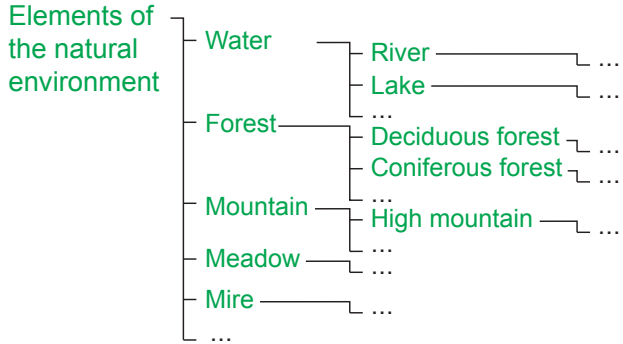

- Mobility space

- Living space in general —-Housing space

- Recreational space - Social space (in the narrower sense)

- Political space

Educational space

Elements of the cultural space

Cooperation space

- Production space in general —_-Sector 1 (agriculture and forestry)

- Consumer space $\quad$ - Sector 2 (industry and commerce)

- Space of identification

Sector 3 (services)

- Experiential space in general $\longrightarrow$-Nature experiencing space

- Space of symbols $\quad$ Experimental cultural space

- Harmonic space

Research space

-Fun-sport-action space

- Viewing space

- Space of problems

Space of ecological problems

Space of socio-economic problems

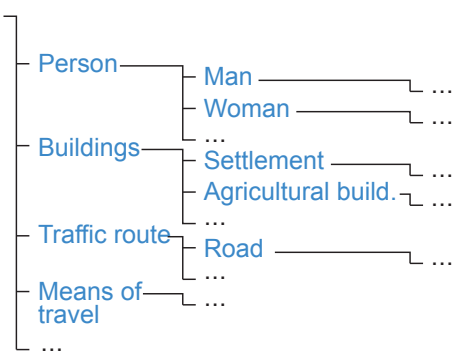

Fig. 3. A simplified depiction of the abductive development of the categories that moves back and forth between normative-theoretical considerations and descriptive observations. Suspension points signal the almost endless possibilities to further differentiate the categories (graph by U.M.).

\subsection{Inclusion of the image context}

The effect of images highly depends on how and where they are placed, i.e. the publication and the text that accompanies them (cf. Bignell, 2002:46f.). This study takes this placement into account at different levels. Firstly, the fact that we chose to limit our study to images printed material used for (political) information purposes led us to omit certain types of visual information (e.g. flags, postcards) and fields (i.e. tourism). Secondly, there was no mixing of images in different publications - an overview was made of each one separately. The characteristics of different publications (i.e. resources, appearance, target audience) were only compared during the interpretation of the results and the comparison of different media.

The accompanying text is the greatest factor in the impact an image has, as it is the dialectic relation of word and image that creates meaning (cf. Mitchell, 1990:52). Just as the target audience is influenced and guided by the text, paral- lel analysis of the text hones the categorisation. For instance the text helps the reader to understand the importance of a person, a building, or a landscape, in a way that is impossible from analysis of the image only. The text can also lead to a complete change in the meaning of an image (Barthes, 1993:945) and even "negate" it (e.g. putting the caption "We don't want the Entlebuch look like that!" below a wilderness picture).

\subsection{Analysis and interpretation}

Finally, we wish to draw the categories of images from a publication together and gain an overview of the spatial appropriations shown by their sum total. These overviews then allow us to make a comparison between different publications. In a way, we produce more sophisticated and extensive "area statistics" of the specific region; however, not of its "real" space but of its pictorial representation in the publications we have analysed (see Fig. 4). 


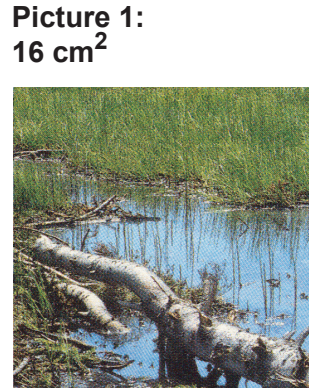

Natural

environment

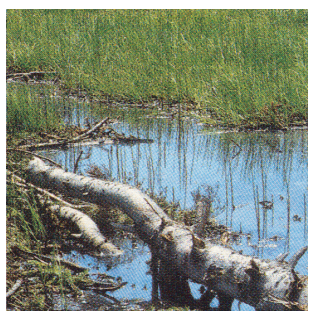

Natural

environment

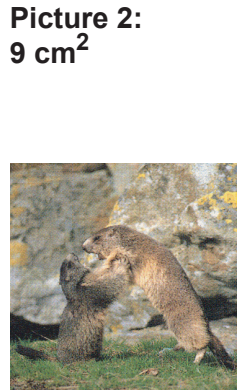

Natural environment

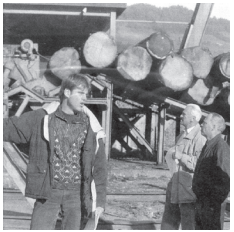

Living space (education)

Production space (sector $1+2)$

Space of identification

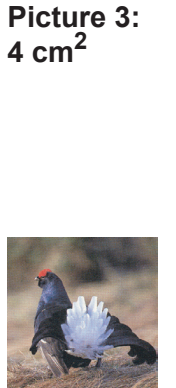

Natural environment
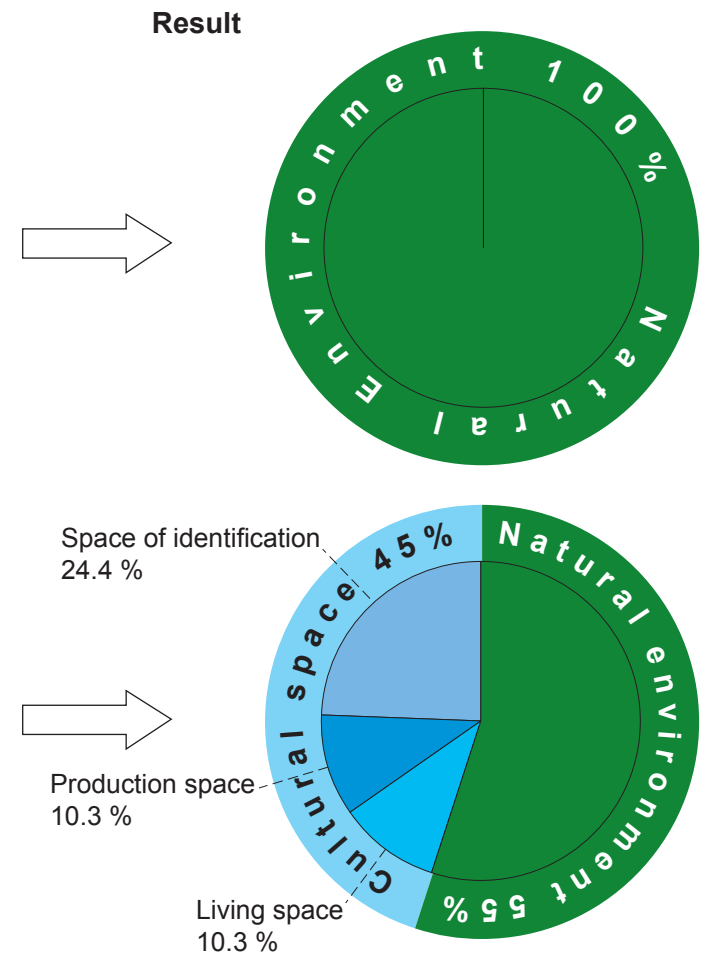

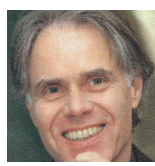

Space of identification $10.3 \%$

Fig. 4. Illustration of the analytic process: from area proportional categorisations of single images to weighted overviews (graph by U.M.).

Similarly to area statistics, the combined area of all individual images in a publication is taken to represent $100 \%$. The categories are weighted by surface area of each image, because eye-tracking research has discovered that the size of an image is central for the attention it gets. Size is also more important than colour (Lester, 2003:50; Kroeber-Riel, 1993). If all images in a publication are coded as natural space, the result would come out as $100 \%$ uninhabited area (see Fig. 4, top). Since some sub-categories of cultural space are not exclusive, it is possible that several such sub-categories apply to the same image. In this case, their weight factor is divided by the number of sub-categories represented (for instance the image in Fig. 4 bottom middle, which at the same time is categorised as "living space", "production space", and "space of identification"). The same procedure is applied to analyse secondary forms of spatial appropriation and the categories "capital intensity" as well as of "gender of figures of identification".

The generated overviews have then to be interpreted (cf. Rose, 2001:54f.). To do this, we compare them with values commonly ascribed to the Alps, to nature, and to cultural landscapes, as mentioned in Bourdeau (1998), Brechbühl and Rey (1998), Glauser and Siegrist (1997), Hunziker (2000), Rolshoven and Winkler (1999), Stremlow (1998, 2004), Wildburger et al. (1996) among others. We can thus see whether the representations of space that we analyse follow the well-known dichotomy between a romantic external view and an everyday, internal view (cf. Stremlow, 1998). Detailed analysis of the history of the projects in the case study areas, with interviews and discourse analysis, allows us to understand the reasons behind the choice and impact of specific images in a specific context. For the "power of images" is revealed against a background of socio-historical values of the viewer (Barthes, 1993:942). However, reliability of the results should be tested in interaction with the subjects of investigation. For this purpose we created an interactive exhibition with public discussions. Yet, an account of the exhibition as a research method would go beyond the scope of this article (cf. Backhaus et al., 2006).

\section{Case study of the UNESCO Biosphere Entlebuch}

The methods outlined above will be applied to three publications concerning the Entlebuch biosphere reserve. They were published both before and after the crucial referendum on Entlebuch's application for the UNESCO label and targeted different audiences. However, before we do so, we should say a few words about the Entlebuch biosphere itself. 


\subsection{UNESCO Biosphere Entlebuch (UBE)}

"Amt Entlebuch" (engl. district of Entlebuch) is the denomination of a region in the canton Lucerne in the foothills of the Alps, covering roughly one percent of Switzerland's area or $410 \mathrm{~km}^{2}$. However, the biosphere does not cover the "Amt" but the planning region of Entlebuch $\left(394 \mathrm{~km}^{2}\right)$, excluding the municipality of Wolhusen. In 2002, the eight municipalities (Doppleschwand, Entlebuch, Escholzmatt, FlühliSörenberg, Hasle, Marbach, Romoos and Schüpfheim) had a population of 16642 . This number is more or less the same as in 1850 , which is an indicator of its stagnating development (AfS, 2004:579). A large proportion (36.5\%) of the economically active population is employed in the agricultural and forestry sector, compared with a Swiss average of only 5.8\% (cf. Schmid, 2004). By average income, the Entlebuch is one of the poorest regions in Switzerland and therefore suffers from a high tax burden (in Switzerland, each municipality can determine its own tax rate dependent on its financial power). The Entlebuch is regarded as the "poorhouse of Switzerland" (Ruoss, 2001:128).

On September 20th 2001, UNESCO recognised the Entlebuch as a biosphere reserve. This happened after the population had voted in favour of the candidature in 2000 . Roughly $10 \%$ of the population with the right to vote participated in the assemblies at municipality level, and the legitimate body for such votes. This appears very low, but for this kind of poll, where people have to travel long distances to take part in the assembly and for a political system where at least four votes (not including elections) are held per year, it is actually fairly high. However, the result was crystal clear: $90 \%$ voted in favour of the candidature as a biosphere reserve. This was a novelty in the 25-year history of biosphere reserves, because the inhabitants of such a region had never before been asked to vote on a project (Ruoss et al., 2002:4). Hence the redefinition of the Entlebuch as a biosphere reserve was a self-determined act by those Entlebuchers entitled to vote.

But what is a biosphere reserve? On current understanding, biosphere reserves are characterised by integral efforts to achieve economic growth, which is ecologically and socially compatible (cf. UNESCO, 1995). Thus, biosphere reserves can be regarded as testing grounds for sustainable development.

There are two main distinctions between biosphere reserves and other "normal" landscapes. On the one hand, they possess large, valuable, and representative natural features. On the other hand their inhabitants seek "to prosper without using the diverse landscape beyond its regenerative capacities and without taking more than can grow back" (UNESCO Biosphäre Entlebuch, 2004). The aims of protection and development are expressed in the biosphere reserve's zoning scheme, which consists of a core zone, in which nature conservation must be ensured by long-term regulation (i.e. protection laws), and a development zone where sustainable development of settlements and cultural landscapes must be possible. The transition between the two is cushioned by buffer zones. In addition to these dual aims of protection and development, the management of the biosphere reserve must provide logistical help for environmental education, research and monitoring. This entails coordinating projects, facilitating people's own initiatives and setting participative processes in motion. Since the establishment of a biosphere reserve is a long-term endeavour, the local population should have a say in its development (cf. Ruoss et al., 2002:9).

\subsection{Results of the image analysis}

In this section, we present the results of the analysis of three publications including 117 photographs or diagrams. First of all, we examine under which categories of spatial appropriation the Entlebuch's project to become a UNESCO biosphere reserve was depicted and perceived from outside the region. As an example, we took a magazine (Schweizer Familie) that has the German-speaking part of Switzerland as its target audience. The magazine represents the outsiders view accurately as a comparison with other print media published from outside the Entlebuch demonstrates (cf. Erne et al. 2003). Secondly, we look at the insider or internal view through the example of an information brochure that was distributed to all Entlebuch households before the crucial referendum. Again, the chosen example is a typical representative for the inside view as the analysis of all articles in the regional newspaper Entlebucher Anzeiger showed (interestingly, though the regional newspaper and the information brochure have both different functions and production contexts the therein depicted appropriation of the Entlebuch is very similar). Our third example is designed to evaluate whether this inside view had changed two years on from the UBE's inauguration in 2001.

\subsubsection{The outside view}

The magazine "Schweizer Familie" was founded in 1893 and calls itself "the family magazine of Germanspeaking Switzerland" (http://www.tamedia.ch/dyn/d/ schweizerfamilie/index.html, 4.5.2005). It appears weekly with a print run of 165064 (WEMF AG, 2003) and belongs to Tamedia AG, which also publishes the "Zürcher Tages-Anzeiger". On 13 November 2001, approximately three weeks after the UBE's recognition by UNESCO, "Schweizer Familie" published a seven-page article about the newly-established biosphere reserve, under the title: "In der Natur liegt die Zukunft" ("The future lies in nature"). The seven pages include ten photographs and one graphic illustration.

The results of the image analysis according to the categories of spatial appropriation show that the proportion of natural space images is remarkably high $(85.8 \%)$ : The article presents a very natural Entlebuch. $6.2 \%$ of image surface area falls within the "harmonic space" category, referring to 


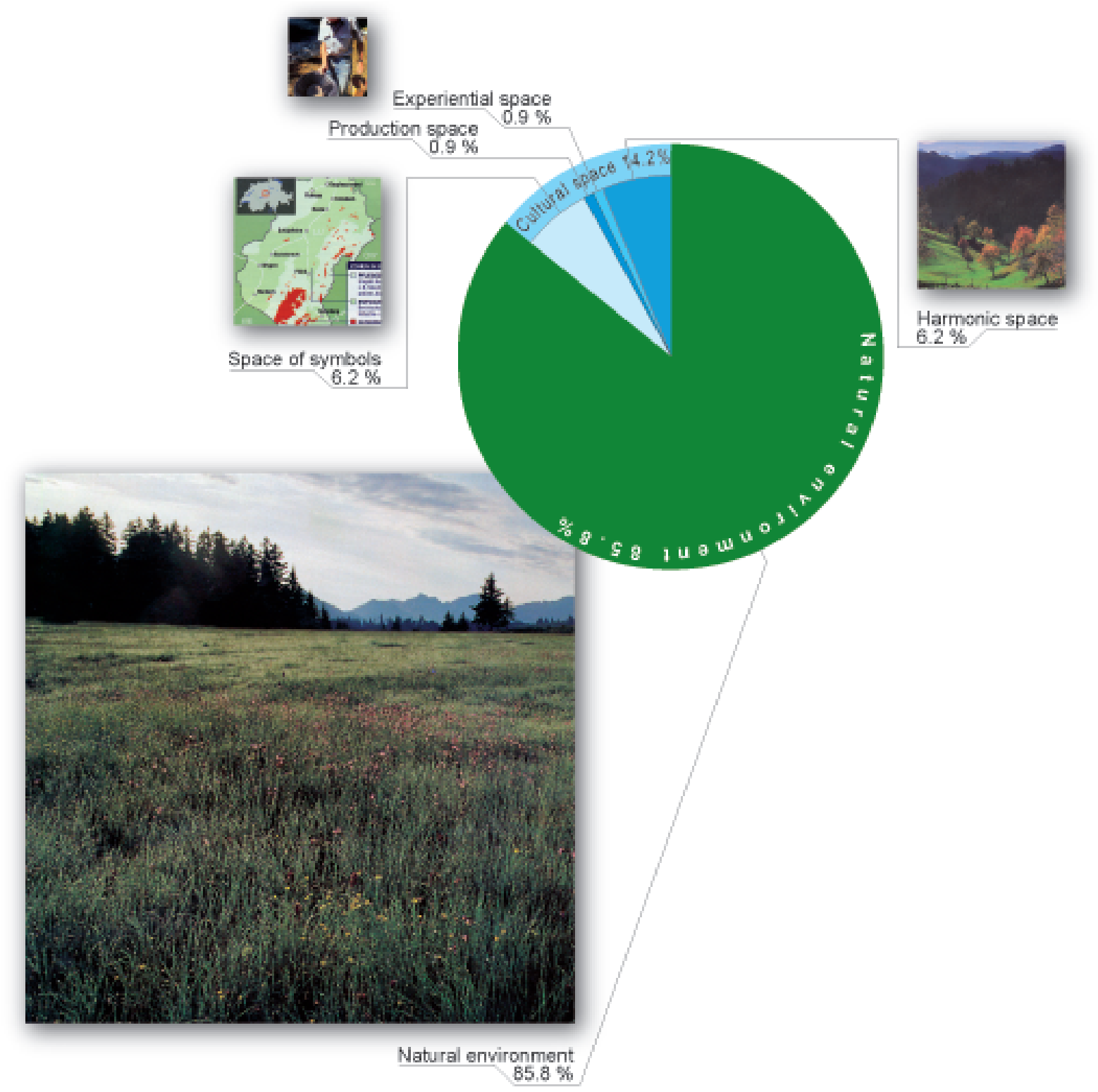

Fig. 5. The view from outside the Entlebuch: Article "In der Natur liegt die Zukunft" (Schweizer Familie, Nr. 37, 2001:22-28). The images have been analysed in terms of the primary occurrences of spatial appropriations (graph: U.M., photos: Max Schmid).

a "typical", aesthetically-staged cultural landscape, reminiscent of a calendar. The only person shown in the images is a man panning for gold. This image makes up $1.8 \%$ of the image surface area of "adventure" and "economic" space.

It is interesting that the verbal and visual presentations of the Entlebuch differ appreciably. For instance, the main focus of the text is on the "modern working environment" the Entlebuch provides, the importance of agriculture, the emigration of young Entlebuchers, the declining population, the "model farm Birkenhof", healthcare contributions, and the fact that the Entlebuchers should learn to think beyond their own parochial politics (p. 26 et sqq.). It is an innovative
Entlebuch that is described, in which people live and work, one that recognizes its problems and tries to overcome them; yet a beautiful "picture-book", "paradisiacal" Entlebuch is the one pictured.

As the example of "Schweizer Familie" shows, the outside view of mountain areas is often romanticised and romanticising, idyllic and idealised, and has little in common with local people's lives. The idea of the Entlebuch represented by the article in "Schweizer Familie" is relatively typical of the outside view - at least before the establishment of the UBE (see below): the publication presents a largely natural, idyllic Entlebuch. The images are in the "tradition of the 
picturesque" (Hennig, 1999:106) that exerts a strong emotional appeal on its audience and that is therefore the "best advertisement" for the Entlebuch. To put it emotively, it is a "calendar landscape, a landscape where the visitor's heart blooms" (Bundi, 2003).

In terms of the visualization of sustainable development, the image selection shows how those people involved in the production and selection of images perceive the project. From their point of view, the UBE seems to be a nature and landscape conservation project, at the most a gentle valorisation of an intact, picture-book landscape. The illustration chosen gives an impression that the primary concern of this model region for sustainable development lies in nature conservation or in preserving outstanding landscapes. This occults a much broader, multidimensional meaning of sustainable development, and the model character of the region's development efforts are simplified. Sustainable development would appear to equal protecting and conserving; its progressive and innovative aspect is not shown at all. Therefore, the risk of excluding people that do not feel addressed by the ecological dimension or that are even repelled by conservation issues is quite high (cf. introduction).

\subsubsection{The inside view}

The brochure "Das Entlebuch, ein Biosphärenreservat" ("The Entlebuch, a biosphere reserve", see Fig. 6) was published by the biosphere reserve's management and distributed - to households in the eight concerned municipalities in September 2000 - directly before the referendum. Along with the articles published in the regional newspaper, the "Entlebucher Anzeiger", this brochure was the most important source of information for the inhabitants of the Entlebuch. It contains 12 coloured A4 pages and includes 38 photographs and 3 graphic illustrations (including 1 map).

The brochure presents the Entlebuch as a (relatively modern) residential and economic area (production space and living space together amount to over $50 \%$ of the image surface area), which is characterised more by modern "high-tech" constructions than by traditional artefacts or activities. Two categories of spatial appropriation, "residential space" and "economic space", apply to more than half of the overall image surface area. On the other hand, the two categories "natural environment" and "harmonic space" together only constitute 5 percent of the image area! Thus the Entlebuch was neither presented as natural environment, nor as an idyllic cultural landscape. Nature does not even play an important role as background scenery: $95 \%$ of the image surface area is constituted by dominant images of cultural space.

The category "symbolic space" is the third most frequent category (18\%). Although there are only three graphic illustrations, these illustrations have a very large surface area. One of them shows a map of the Entlebuch, but without the planned zoning scheme.

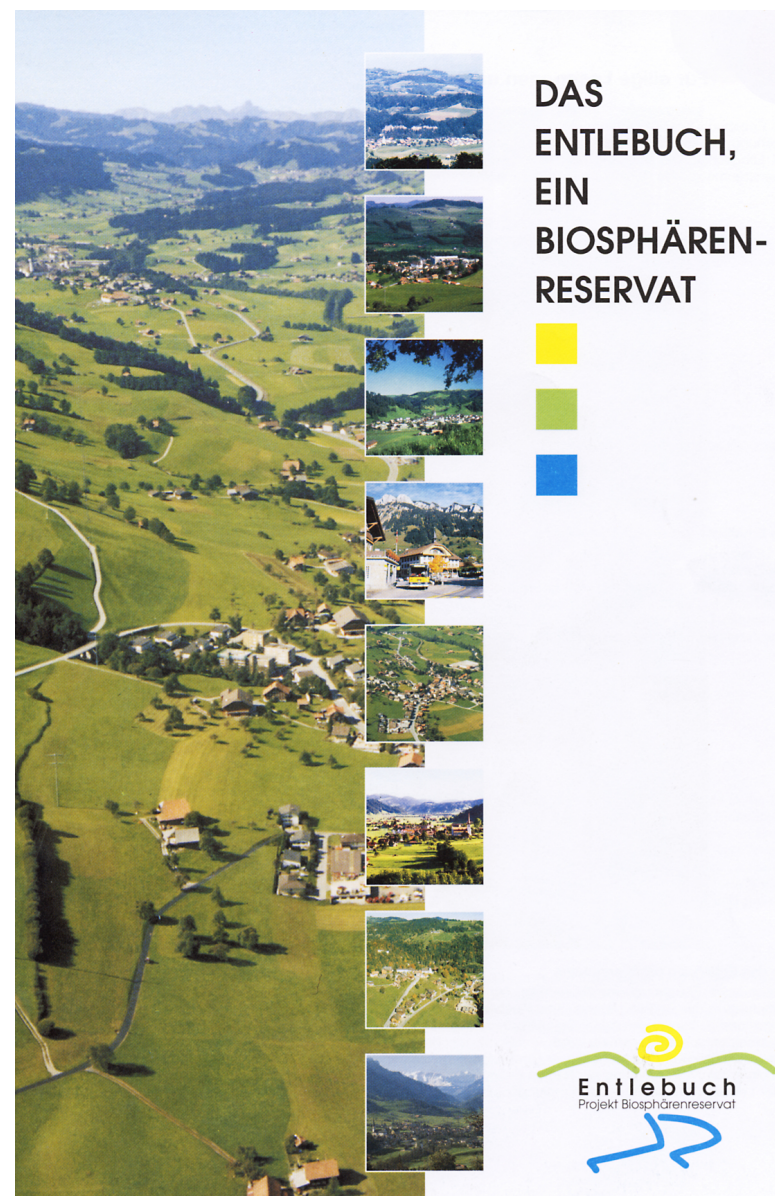

Fig. 6. Cover page of the voters' information brochure "Das Entlebuch, ein Biosphärenreservat", September 2000.

The high percentage of the category "identification space" is largely due to four (staged) photographs on the last page of the publication. These photographs show local "personalities" who support the biosphere reserve project, talking about the opportunities the project will give them. The other images of this category show regional produce with the biosphere logo and there is one picture of the important local pilgrimage site of "Heiligkreuz".

None of the images portrays the Entlebuch as an ecological "problem space", for instance as a space affected by thunderstorms. However, if one takes a look at the regional newspaper's, the "Entlebucher Anzeiger", coverage of the area, excluding articles on the biosphere reserve, one discovers that natural disasters are one of the most pictured topics. Such "blind spots" in the representation of the region are noteworthy when related to the on-going discussion process about problems, targets and measurements.

Likewise, one finds no images belonging to the category "political space". In contrast to the picture reports in the "Entlebucher Anzeiger", there are no images in the voter information brochure referring to "cooperation" either. In addi- 


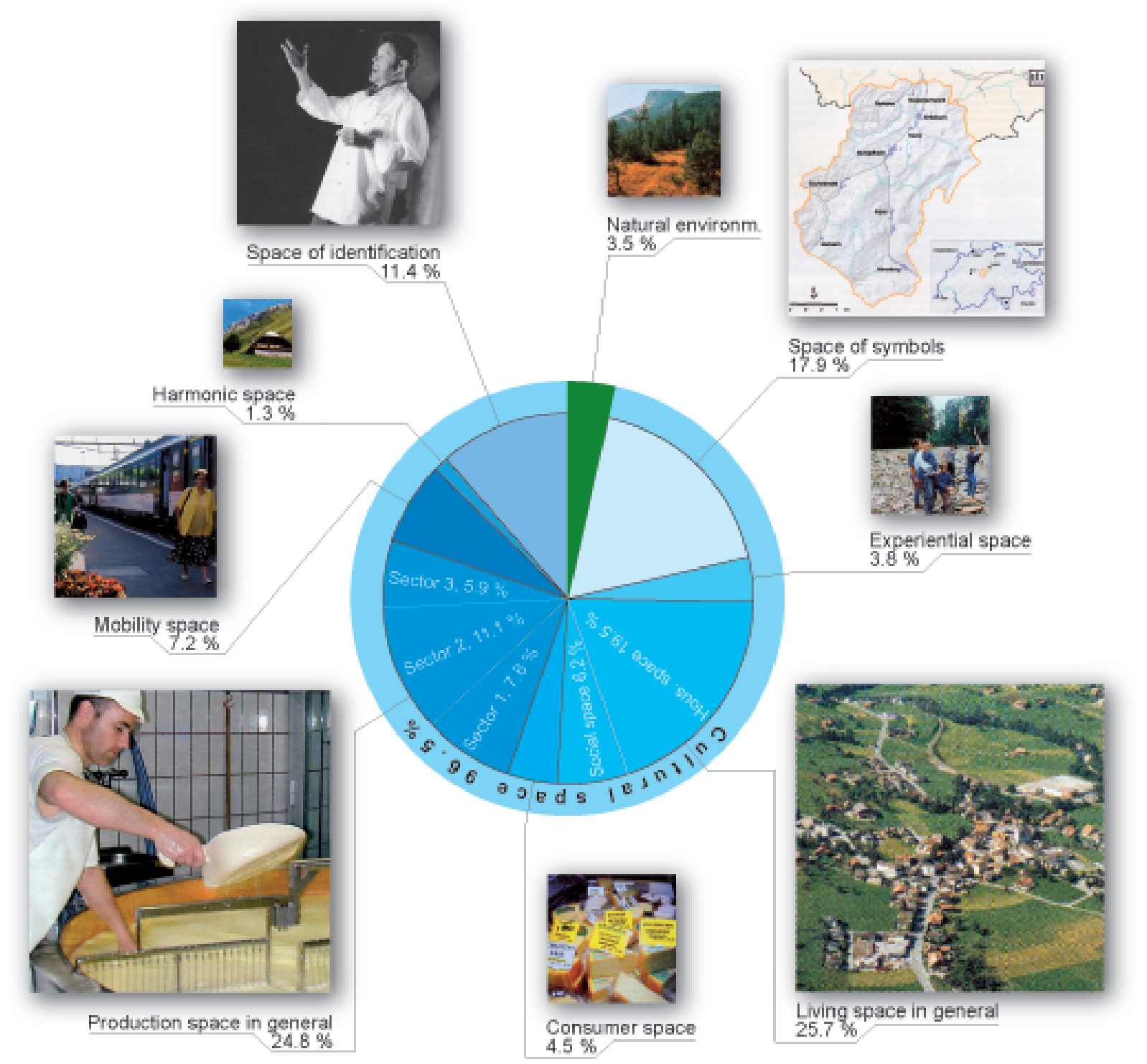

Fig. 7. The "image of the Entlebuch" as presented in the voters' information brochure "The Entlebuch, a biosphere reserve" from September 2000. The images have been analysed in terms of the primary occurrences of spatial appropriations (graph: U.M., pictures: UNESCO Biosphere Entlebuch).

tion, issues of fundamental interest to the younger generation of the Entlebuch are not addressed in the pictures: education is invisible, sport and leisure activities are hardly represented $(0.9 \%$ of the image surface area) and there is nothing about cultural activities or meeting places for adolescents. There is no adolescent among the "personalities" pictured either.

What sense should we make of this inside view? Why does the UBE not present itself in a more natural and idyllic way? We would like to pick up on three central aspects of the Entelbuch's socio-cultural context that help us to understand the UBE's presentations better.
1. We should start by mentioning that, until the beginning of the biosphere reserve project, the Entlebuch was, visually at least, something of a "terra incognita". The region is, for example, not mentioned in the Merian guides of 1975 and 1991, nor are the region's sights recorded on the therin included maps of Switzerland in contrast to the neighbouring Emmental region. The region needs to call attention to itself in order to improve its chances in the tourism business, as well as in the marketing of its regional produce. It can now boast of being the first region in Switzerland to have received the UNESCO biosphere reserve label. At the 
very least since the successful referendum, but above all since the official recognition of the UBE, the Entlebuch is frequently mentioned in all national and many international media (cf. Erne et al., 2003). Whilst reports like the one presented in "Schweizer Familie" continue to reproduce picturesque clichés, the promoters of the UBE are constructing a modern and everyday inside view of itself, even though this is undoubtedly less attractive to tourists. The reasons for this can be found in the following two contextual specificities.

2. For many Swiss, the Entlebuch "enjoys" an unfavourable reputation. In 1985, the Swiss National Science Foundation published the results of a study about regional income disparities in Switzerland (Fischer, 1985). This study led to the Entlebuch being known as the "poorhouse of Switzerland" (Ruoss, 2001:128), a low-income, backward, very traditional agricultural region. A survey revealed that adolescents from the Entlebuch complained of being regarded as "hillbillies", "country bumpkins", as "from the back of beyond" (Probst, 1999) - even in the nearby town of Lucerne. One of the most important motivations to become a biosphere reserve was to rid themselves of this negative perception. This explains why the protagonists of the Entlebuch emphasize the modern and innovative side of the Entlebuch region.

3. The central reason why natural beauty has been excluded from the inside view is to be found in the socalled initiative of Rothenthurm of December 7th 1987. The Rothenthurm initiative was a nationwide referendum intended to prevent the construction of a military training ground in the moorlands of Rothenthurm, in the canton of Schwyz. Rather surprisingly, the majority of the Swiss voted in favour of the initiative. This had significant consequences: The initiative's authors designed it so as to put not only the moors of Rothenthurm under protection but all "moors and marshland of special beauty and national importance" (Swiss Federal Constitution, Art. 78, Abs. 5). The acceptance of the initiative resulted in the inclusion of $26 \%$ of the surface area of the Entlebuch as protected high moors, marshlands or moorlands. Thanks to this initiative, the core and buffer zones of the future biosphere reserve had already been regionalized as protected areas. Therefore, the biosphere reserve did not have to be presented as a nature conservation project because it did not imply any further resource use limitations. A nature conservation project would have had little chance of being accepted, due to the high percentage of the population involved in agriculture. The negative experiences particularly farmers had of the Rothenthurm initiative - many of them faced land "expropriations" - were too "sustainable".

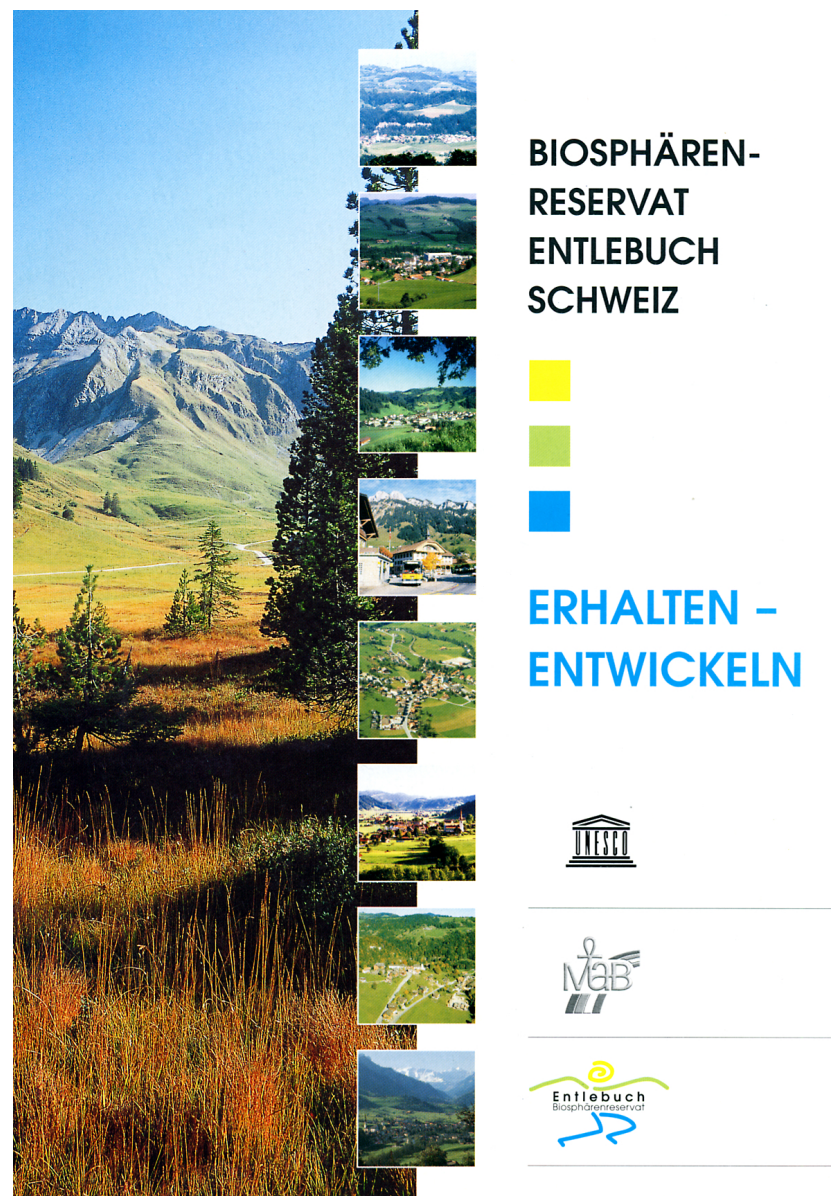

Fig. 8. Cover page of the second, updated edition of the former voters' information brochure, 2002.

4.2.3 Changing views: the updated voter information brochure

The differences between the inside and the outside perspectives are clear from the presentation above. However, a clear change both of the inside and of the outside view has taken place since the inauguration of the UBE. The outside view has tended to adopt the inside perspective, and vice versa.

To show this change in the inside view, we looked at the new information brochure that appeared two years after the first edition. This second, updated edition was published under the title "Biosphärenreservat Entlebuch Schweiz: Erhalten - Entwickeln" ("Biosphere Reserve Entlebuch Switzerland: Conserve - Develop". While the volume and format remain identical, the brochure now contains 62 photographs -24 more than in the previous publication - and 3 illustrations (including one map).

The overall impression of the publication is more colourful, as well as richer in contrast. A remarkably aesthetic image of a moorland landscape, illustrated in bright colours and accentuated contrasts (cf. Fig. 8), has replaced the rather dull 


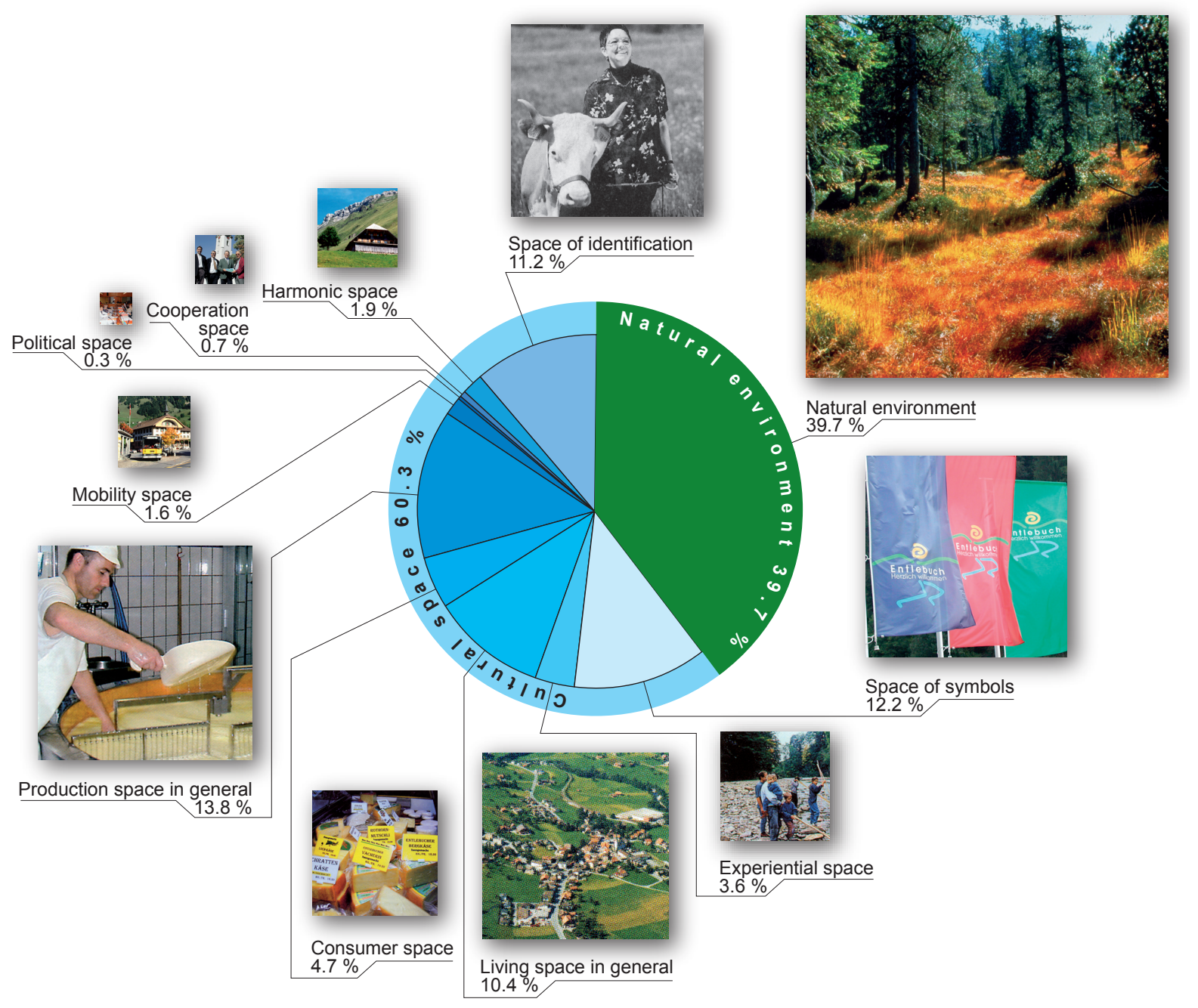

Fig. 9. The image of the Entlebuch in the updated information brochure of 2002 "Biosphärenreservat Entlebuch Schweiz - Erhalten Entwickeln". Image analysis according to primary occurrences of space appropriations (graph U.M., fotos: UNESCO Biosphere Entlebuch).

cover picture of the previous edition (a bird's eye view of the main valley of the Entlebuch, cf. Fig. 6). The slightly modified title ("Biosphere Reserve Entlebuch Switzerland") now explicitly refers to the Entlebuch as a part of Switzerland and thereby makes the region identifiable for an international audience. While the small-scale pictures of the eight municipalities involved have been retained, logos now allude to the intervening recognition of the biosphere reserve by UNESCO.

A comparison of the image analysis of the two information brochures shows (cf. Fig. 7 and 9) that the proportion of the spatial appropriation category "natural environment" has soared to $39.7 \%$, a tenfold growth! The Entlebuch is now shown as a natural landscape, "at the expense" of the residential space and economic space image surface area, whose combined weight decreased from $50 \%$ to less than $25 \%$.
"Space of identification" and "harmonic space" take up more or less the same area as before. the new, relatively small images of "cooperation space" and "political space" have now been added.

The inside view shows decidedly more "natural environment" space than two years earlier. Thus, the values of the target groups outside the region have been taken into account. On the one hand, aesthetic pictures of nature and idyllic images of cultural landscapes appeal to an outside audience (cf. Hennig, 1999). On the other hand, there is a clear intention to make the local population aware of the Entlebuch's natural beauty. Now that the biosphere preserves installation is accepted, and its economical and social values are broadly understood, both the depiction and discussion of wilderness and landscape conservation issues seem to become possible again. In the light of this rapprochement between the in- 


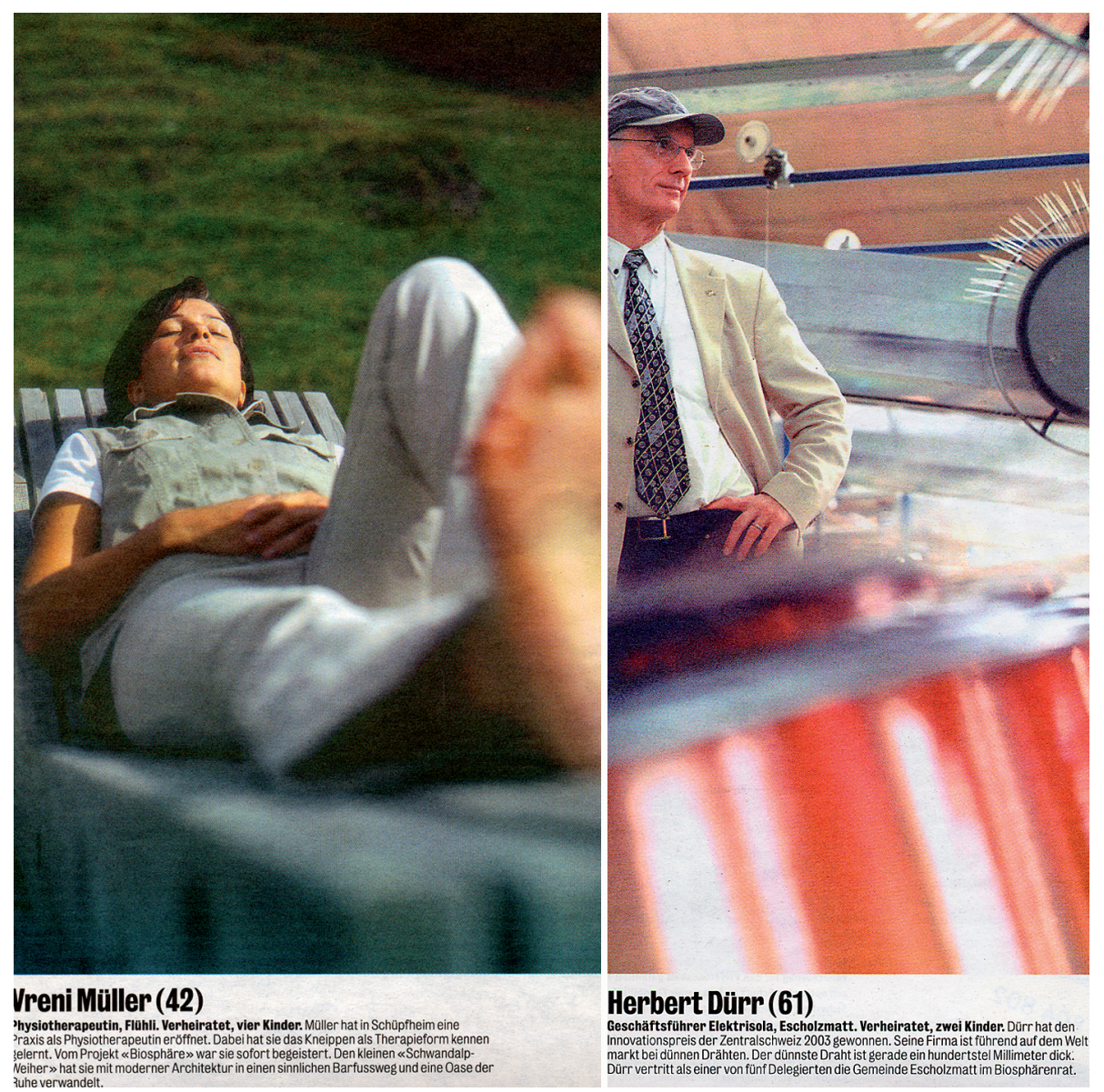

Fig. 10. The outside view is starting to take notice of the Entlebuch's upturn and the people who made it possible and therefore goes beyond the usual clichés (fotos: Franca Pedrazzetti, Magazin des SonntagsBlick, 10.10.2004, p. 6 and 8).

sider's view to the clichés the outsider has of the region, we can only hope that the UBE will also present its innovative achievements in the field of sustainable development (i.e. regional produce, cooperation, education programmes, etc.), and whether it will be able to assert itself in a hard-fought market. This will be important, as outsiders are starting to take notice of the Entlebuch's upturn and in the people who made it possible. This transmits a new image of rural regions, which goes beyond the usual clichés to the outside world. An article about the UBE in the Sonntagsblick magazine (10 October 2004:1-6) depicts it as "identification space", showing photographs of the pioneers (see Fig. 10).

\section{Conclusions}

Image analysis gives us access to often unreflected mental images or ideas of image producers and consumers. These are what Giddens, in his theory of structuration, considers to be the real motivations for action. For the image producer, the choice of images either directly follows the producers' personal values or is strategically aimed at appealing to the assumed values of the target audience. The image's impact depends on the extent to which they can appeal to values, arouse emotions and - with the help of the textual context motivate the viewer to act in a specific way. Image analysis of both sides allows us to identify people's habits without their needing to express this verbally. Image analysis is therefore a useful method to complement interviews, as the conducted interviews with image producers made obvious (cf. Müller, 2006b).

The context of an image is crucial for its interpretation, its choice and its impact. For it is the context that "makes" the image, that limits the range of possible meanings and focuses the viewer's attention on what is important. Therefore, image analysis conducted out of context is incapable of determining what effect the image has on people's actions. However, a comprehensive consideration of an image's context is a "boundless task". Even if we can ascertain the collective factors, which influence the context, we are faced with the problem that the actual impact of an image changes with each person's changing dispositions and attitudes. Depending on the viewer's position, attitude or role, images can take 
on different meanings. To have something significant to say, image analysis must master a complexity that has as yet not been sufficiently researched.

The method of analysing images that we have developed is an attempt to process and analyse a great number of images without neglecting either their context or their link to the question under research. Since an exclusively deductive categorisation is prone to neglect the context and an exclusively inductive categorisation fails to consider the research question and the theoretical background, we opted for an abductive categorisation process, which combines the best of both approaches. However, this entailed the extensive and time-consuming process of developing the categories.

Analysis of the inherent meaning of images does not reveal the actual intentions of the image producers, nor does it show the actual effect of the images on those who consume them. Therefore, complementary methodical approaches have to be deployed. We must nevertheless bear in mind that if image producers are asked retrospectively about their intentions, they often merely justify their habitual and possibly unreflected perceptions and thus their choices. During our research with image producers, we saw that their choice of images was rarely conscious. Discussing alternative visualisations therefore considerably contributed to the manner in which they reflected on their habitual reactions.

Spatial classification and presentation are not rooted in the nature of things but rather in people's socio-culturally influenced interests. People's conceptions of the world tell us more about the needs, values and beliefs of those striving to make some sense of reality than about "reality" itself (Graeser, 2000:298). If we consider spatial presentations as perspectives that depend on a person's standpoint and distance (to landscapes and objects), there is then a need to analyse their "assets". This entails finding out the reasons why certain ideas and views are accepted or rejected or, in other words, deducing which people have the best objective chances of imposing their views (Bourdieu, 1995, 1990).

When combined with the deconstruction of visual representations of space, categories of spatial appropriation are also useful for a conscious construction of spatial images. The categories can be regarded as criteria to hone the eye's appreciation of the different things a region has to offer. We can thereby create complementary perspectives to existing, one-sided views. Enriching the way people perceive a region is, after all, a pre-requisite for successful participatory processes.

Acknowledgements. The authors wish to acknowledge support from the Swiss National Science Foundation (National Research Programme NRP 48 "Landscapes and Habitats of the Alps") and to thank A. Fritschi and S. Pare for their contributions.

Edited by: J. Miggelbrink

\section{References}

Afs (Amt für Statistik Kanton Luzern) (Ed.): Statistisches Jahrbuch des Kantons Luzern 2004, Amt für Statistik, Luzern, 2004.

Bachmann, S.: Zwischen Patriotismus und Wissenschaft - Die schweizerischen Naturschutzpioniere (1900-1938), Chronos, Zürich, 1999.

Backhaus, N.: Ökotourismus in malaysischen Nationalparks - Methodentriangulation in der sozialgeographischen Asienforschung, Asiatische Studien, 55(4), 943-952, 2001.

Backhaus, N., Buschle, M., Gorgus, N., Müller, U., and Moreno, T. (Eds.): Kraft der Bilder. Vorstellungen über Nachhaltigkeit - ein Entscheidungsspiel, Schriftenreihe Humangeographie, Vol. 21, Abteilung Humangeographie, Geographisches Institut der Universität Zürich, Zürich, 2006.

Barthes, R.: Le message photographique, in: Roland Barthes: Oeuvre complètes, Tome 1: 194-1965, edited by: Marty, E., Editions du Seuil, Paris, 938-948, 1993.

Bell, P.: Content Analysis of Visual Images, in: Handbook of Visual Analysis, edited by: van Leeuwen, T., and Jewitt, C., SAGE Publications, London etc., 10-34, 2001.

Bignell, J.: Media Semiotics - an Introduction, Manchester University Press, Manchester and New York, 2002.

Borghardt, J., Meltzer, L., Roeder, S., Scholz, W., and Wüstenberg, A. (Eds.): ReiseRäume - Touristische Entwicklung und räumliche Planung. Dortmunder Beiträge zur Raumplanung 109, Institut für Raumplanung Universität Dortmund, Dortmund, 2002.

Bourdeau, P.: Die Alpen als Turngerät Europas, in: Alpenreport: Daten, Fakten, Probleme, Lösungsansätze, edited by: CIPRA International, Haupt, Bern, Stuttgart, Wien, 252-259, 1998.

Bourdieu, P.: Was heisst sprechen? Die Ökonomie des sprachlichen Tauschs, Braumüller, Wien, 1990.

Bourdieu, P.: Physischer, sozialer und angeeigneter physischer Raum, in: Stadt-Räume, edited by: Wentz, M., Campus, Frankfurt a.M. und New York, 25-34, 1991.

Bourdieu, P.: Sozialer Raum und Klassen, in: Sozialer Raum und Klassen/Leçon sur la leçon, edited by: Bourdieu, P., Zwei Vorlesungen, Suhrkamp, Frankfurt a.M., 7-46, 1995.

Bozonnet, J.-P.: Des Monts et des Mythes - L'imaginaire social de la montagne, Presses Universitaires, Grenoble, 1992.

Brechbühl, U. and Rey, L.: Natur als kulturelle Leistung: zur Entstehung des modernen Umweltdiskurses in der mehrsprachigen Schweiz, Seismo, Zürich, 1998.

Bundi, H.: Letzte Lösung Ballenberg, in: FACTS, 17.3.2005, Zürich, 2003.

BUWAL: Umwelt Schweiz 2002 - Politik und Perspektiven, BUWAL (Bundesamt für Umwelt, Wald und Landschaft), Bern, 2002.

BUWAL: Landschaft 2020 - Analysen und Trends. Schriftenreihe Umwelt Nr. 352, BUWAL (Bundesamt für Umwelt, Wald und Landschaft), Bern, 2003.

Culler, J.: Semiotics of Tourism, in: Framing the Sign: Criticism and Its Institutions, edited by: Culler, J., University of Oklahoma Press, Norman and London, 153-167, 1988.

Erne, F., Ghilardi, V., Rüttimann, K., and Steinmann, B.: Medienresonanz des Biosphärenreservates Entlebuch. Analyse der Medienberichtersattung und des Medienimages des BRE, Projektarbeit Studiengang Wirtschaftskommunikation, HSW Luzern, 2003. 
Fischer, G., Mennel-Hartung, E., and Rutishauser, P.: Räumliche Disparitäten in der Schweiz - Überblick und Bilanz, Publikationen des Schweizerischen Nationalfonds aus den Nationalen Forschungsprogrammen, Vol. 34.3, Paul Haupt, Bern etc., 1985.

Fischer, L. and Hasse, J.: Historical and Current Perceptions of the Landsapes in the Wadden Sea Region, in: Landscape and Cultural Heritage in the Wadden Sea Region - Project Report, edited by: Vollmer, M., Guldberg, M., Maluck, M., Marrewijk, D., and Schlicksbier, G., Common Wadden Sea Secretariat, Wilhelmshaven, 72-97, 2001.

Flick, U.: Triangulation in der qualitativen Forschung, in: Qualitative Forschung, Ein Handbuch, edited by: Flick, U., Kardoff, E., and Steinke, I., Rowohlt, Reinbek, 309-318, 2000.

Gamper, C., Liska, G., and Strohmeier, G.: Projektbereich Raumbilder. Forschungsschwerpunkt Kulturlandschaft: Kulturlandschaft im Kopf, iff, Wien, 1997.

Gibson, J. J.: The ecological approach to visual perception, Lawrence Erlbaum Associates, Hillsdale, NJ and London, 1986.

Giddens, A.: The Constitution of Society: Outline of the Theory of Structuration, Polity Press, Cambridge, 1984.

Glauser, P. and Siegrist, D.: Schauplatz Alpen - Gratwanderung in eine europäische Zukunft, Rotpunktverlag, Zürich, 1997.

Graeser, A.: Bedeutung, Wert, Wirklichkeit - Positionen und Probleme, Lang, Bern, 2000.

Hard, G.: Regionalisierung, in: Region, edited by: Wentz, M., Campus, Frankfurt and New York, 53-57, 1994.

Hennig, C.: Reiselust - Touristen, Tourismus und Urlaubskultur, Insel Verlag, Frankfurt a.M. etc., 1999.

Hunziker, M.: Einstellungen der Bevölkerung zu möglichen Landschaftsentwicklungen in den Alpen, Eidg. Forschungsanstalt WSL, Birmensdorf, 2000.

Ipsen, D.: Raumbilder, Centaurus, Pfaffenweiler, 1997.

Jäger, S.: Discourse and Knowledge - Theoretical and methodological aspects of a critical discourse and dispositive analysis, http://www.diss-duisburg.de/Internetbibliothek/ Artikel/Discource\%20and\%20Knowledge\%20.pdf, 2001.

Kollmair, M., Müller-Böker, U., and Soliva, R.: The Social Context of Nature Conservation in Nepal, European Bulletin of Himalayan Research, 24, 25-62, 2003.

Kroeber-Riel, W.: Bildkommunikation: Imagerystrategien für die Werbung, Franz Vahlen GmbH, München, 1993.

Lester, P. M.: Visual Communication: Images with Messages, Wadsworth, Belmont, Calif., 2003.

Luhmann, N.: Die Realität der Massenmedien, Westdeutscher Verlag, Opladen, 1996.

Löw, M.: Raumsoziologie, Suhrkamp, Frankfurt a.M., 2001.

Mitchell, W. J. T.: Was ist ein Bild? in: Bildlichkeit, edited by: Bohn, V., Suhrkamp, Frankfurt a.M., 17-68, 1990.

More, T. and Turner, P.: Utopia, Penguin Books, London, 2003.

Müller, U.: Die Kraft der Bilder in der nachhaltigen Entwicklung. Die Fallbeispiele UNESCO Biosphäre Entlebuch und UNESCO Weltnaturerbe Jungfrau-Aletsch-Bietschhorn, Dissertation an der Mathematisch-naturwissenschaftlichen Fakultät der Universität Zürich, 2006a.

Müller, U.: Die Macht der Bilder in der nachhaltigen Entwicklung, in: Kraft der Bilder, Vorstellungen über Nachhaltigkeit - ein Entscheidungsspiel, edited by: Backhaus, N., Buschle, M., Gorgus, N., Müller, U., and Moreno, T., Schriftenreihe Humangeographie, Vol. 21, Geographisches Institut der Universität
Zürich, Zürich, 21-49, 2006b.

Müller, U. and Kollmair, M.: Die Erweiterung des Schweizerischen Nationalparks: Der Planungsprozess 1995-2000, betrachtet aus partizipationstheoretischer Sicht, DISP 159 (4/2004), 44-51, 2004.

Müller-Doohm, S.: Bildinterpretation als strukturalhermeneutische Symbolanalyse, in: Sozialwissenschaftliche Hermeneutik - Eine Einführung, edited by: Hitzler, R. and Honer, A., Leske und Budrich, Opladen, 81-108, 1997.

Probst, L.: "Irgendwie heimelig" und "manchmal ziemlich langweilig", in: Lebenszeiten im Entlebuch, edited by: Scagnet, E., Duss-Studer, H., Ehrler, J., Küng, J., Lohri, P., Probst, L., and Schmidiger, A., Verlag Druckerei Schüpfheim, Schüpfheim, 1999.

Reutlinger, C. T.: Jugend, Stadt und Raum - Sozialgeographische Grundlagen einer Sozialpädagogik des Jugendalters, Leske und Budrich, Opladen, 2003.

Rodewald, R.: Sehnsucht Landschaft - Landschaftsgestaltung unter ästhetischem Gesichtspunkt, Chronos, Zürich, 1999.

Rolshoven, J. and Winkler, J.: Berge, Menschen und Dinge - Eine Annäherung an Schweizer Alpen-Passionen, in: Berg-Bilder: Gebirge in Symbolen - Perspektiven - Projektionen, edited by: Becker, S. and Dieterich, C.-M., Hessische Blätter für Volks- und Kulturforschung, Jonas Verlag, Marburg, 81-96, 1999.

Rose, G.: Visual Methodologies - An Introduction to the Interpretation of Visual Materials, SAGE Publications, London etc., 2001.

Ruoss, E.: The Biosphere Reserve as Living Space: Linking Conservation, Development and Research, Mountain Research and Development, 21(2), 128-131, 2001.

Ruoss, E., Schmid, B., Schnider, T., and Hofstetter, H.: Anerkennung des Biosphärenreservats Entlebuch (BRE), in: Das Modell Entlebuch: Grobkonzept Biosphärenreservat Entlebuch Januar 2002 (Berichte aus der Region Entlebuch 2), edited by: Ruoss, E., Schmid, B., Schnider, T. and Schmid, A., Berichte aus der Region Entlebuch 2, Regionalmanagement Biosphärenreservat, Schüpfheim, 3-4, 2002.

Röper, M.: Planung und Einrichtung von Naturschutzgebieten aus sozialgeographischer Perspektive: Fallbeispiele aus der Pantanal-Region (Brasilien), Geographisches Institut, Tübingen, 2001.

Scheff, T. J.: Microsociology - Discourse, Emotion, and Social Structure, University of Chicago Press, Chicago, Ill. etc., 1990.

Scheller, A.: Frau Macht Raum - geschlechtsspezifische Regionalisierungen der Alltagswelt als Ausdruck von Machtstrukturen, Schriftenreihe Anthropogeographie, Vol. 16, Geographisches Institut der Universität Zürich, Zürich, 1995.

Schmid, A.: UNESCO Biosphäre Entlebuch - Modell für eine nachhaltige Regionalentwicklung? Konzept Zielerreichungskontrolle, Berichte aus der Region Entlebuch, Vol. 3, Biosphärenmanagement UNESCO Biosphäre Entlebuch, Schüpfheim, 2004.

Stegmann, B.-A.: Grossstadt im Image - Eine wahrnehmungsgeographische Studie zu raumbezogenen Images und zum Imagemarketing in Printmedien am Beispiel Kölns und seiner Stadtviertel, Kölner Geographische Arbeiten, Vol. 68, Geographisches Institut der Universität Köln, Köln, 1997.

Stremlow, M.: Die Alpen aus der Untersicht - von der Verheissung der nahen Fremde zur Sportarena. Kontinuität und Wandel von Alpenbildern seit 1700, Haupt, Bern etc., 1998. 
Stremlow, M.: Der geographische Blick auf die Alpen: Bilder, Vorstellungen und Diskurse aus dem deutschsprachigen Raum, in: Alpenwelt - Gebirgswelten: Inseln, Brücken, Grenzen, edited by: Gamerith, W., Messerli, P., Meusburger, P., and Wanner, H., Tagungsberichte und wissenschaftliche Abhandlungen zum 54. Deutschen Geographentag Bern 2003, Deutsche Gesellschaft für Geographie, Heidelberg und Bern, 45-53, 2004.

Swiss Federal Council: Sustainable Development Strategy 2002 - Report of the Swiss Federal Council, 27 March 2002, Bern, 2002.

Thabe, S.: Raum(de)konstruktionen, Leske und Budrich, Opladen, 2002.

UNESCO: The Seville Strategy for Biosphere Reserves, http:// www.unesco.org/mab/BRs/pdf/Strategy.pdf, 1995.

UNESCO Biosphäre Entlebuch: Definition, Entstehung, Aufbau, http://www.biosphaere.ch/pages/frame/fb2_1.html, 2004.

Wardenga, U.: Alte und neue Raumkonzepte für den Geographieunterricht, geographie heute, 23, 8-11, 2002.
Weichhart, P.: Raumbezogene Identität, Bausteine zu einer Theorie räumlich-sozialer Kognition und Identifikation, Erdkundliches Wissen, Heft 102, Franz Steiner, Stuttgart, 1990.

WEMF AG: MACH Basic, Zurich 2003.

Werlen, B.: Gesellschaft, Handlung und Raum - Grundlagen handlungstheoretischer Sozialgeographie, Franz Steiner, Stuttgart, 1988.

Werlen, B.: Sozialgeographie alltäglicher Regionalisierungen Band 2: Globalisierung, Region und Regionalisierung, Franz Steiner, Stuttgart, 1997.

Werlen, B.: Handlungszentrierte Sozialgeographie, Replik auf die Kritiken, in: Handlungszentrierte Sozialgeogaphie - Benno Werlens Entwurf in kritischer Diskussion, edited by: Meusburger, P., Franz Steiner Verlag, Stuttgart, 247-268, 1999.

Wildburger, C.: CIPRA International, and CIPRA International Jahresfachtagung (Eds.): Mythos Alpen, CIPRA (Internationale Alpenschutzkommission), Schaan, 1996. 